\title{
Effect of vitamin A and grazing in some physiological characters and milk production of Meriz does
}

\author{
S.Y. Abdul-Rahman ${ }^{1}$, Kh.H. Sultan ${ }^{2}$ \\ ${ }^{1,2}$ Animal Production Department, College of Agriculture and Forestry, Mosul University, Mosul, Iraq
}

(Received June 13, 2018; Accepted August 1, 2018)

\begin{abstract}
The current study was aimed to investigate the influence of Vitamin A- Palmitate injection and grazing on some physiological and biochemical characters, milk yield and its compositions. Twenty eight Meriz does (2 years aged) after parturition with average body weight $22.57 \pm 0.47 \mathrm{Kg}$, and were randomly assigned into 4 groups ( 7 does/group) treated for 3 months as following: $1^{\text {st }}$ group does were reared on standard ration and injected with $0.05 \mathrm{ml}$ of physiological saline i.m weekly, $2^{\text {nd }}$ and 4 th groups, does were reared on standard ration and injected with vitamin A- Palmitate (50000 IU/doe weekly) as well as grazing for $6 \mathrm{hrs}$. daily for the does in $4^{\text {th }}$ group, 3rd group does were reared on standard ration with $6 \mathrm{hrs}$ grazing /daily. Results showed a significant increase in $\mathrm{Hb}$ and $\mathrm{PCV}$ in $4^{\text {th }}$ group at $1^{\text {st }}, 2^{\text {nd }}$ and $3^{\text {rd }}$ month of treatment. ESR significantly increased in $4^{\text {th }}$ group at $3^{\text {rd }}$ month of treatment, also serum glucose level increased significantly in $2^{\text {nd }}$ and $4^{\text {th }}$ groups at all months of the study, while serum cholesterol level decreased significantly in $4^{\text {th }}$ group at $2^{\text {nd }}$ and $3^{\text {rd }}$ months of treatment. Triglyceride increased at $3^{\text {rd }}$ month in all treatments as compared with control, total protein and albumin increased significantly in $2^{\text {nd }}, 3^{\text {rd }}$ and $4^{\text {th }}$ groups at $2^{\text {nd }}$ and $3^{\text {rd }}$ months of treatment. A significant increase in milk yield and fat $\%$ were recorded in $2^{\text {nd }}, 3^{\text {rd }}$ and $4^{\text {th }}$ treatments in most kidding weeks. Conclusion, results showed that vitamin $\mathrm{A}$ and grazing improved some of physiological, biochemical, body weight and milk yield in Meriz goats.
\end{abstract}

Keywords: Meriz does, Vitamin A, Grazing, blood parameters, milk yield.

Available online at http://www.vetmedmosul.com

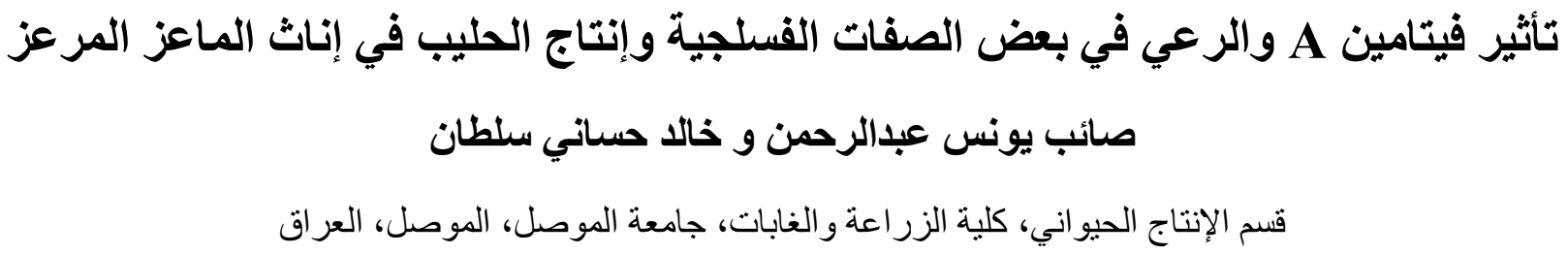

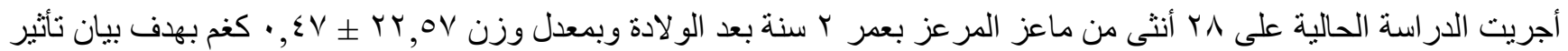

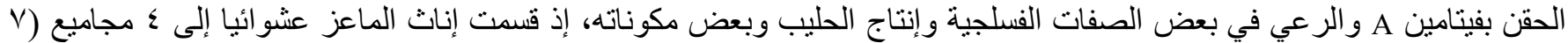

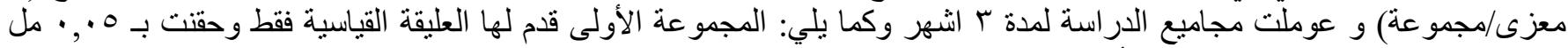

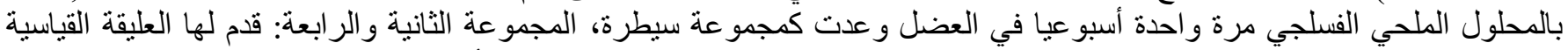

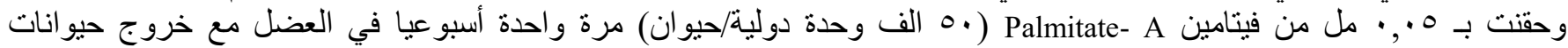

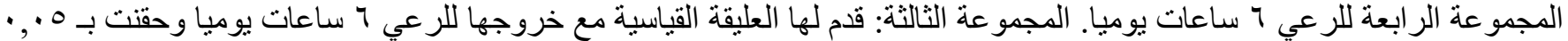

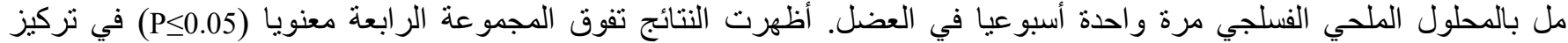

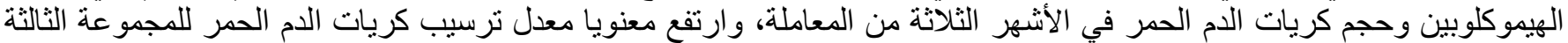

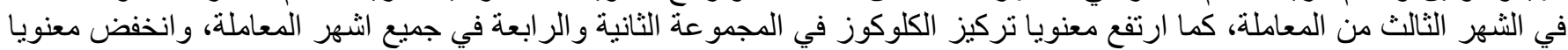

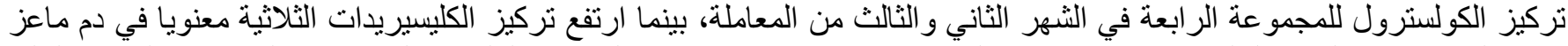
جميع المجاميع في الثهر الثالث مقارنة بمجموعة السيطرة، وارتفع معنويا تركيز البروتين الكلي والالبومين في المجموعة الثانية والثالثة 


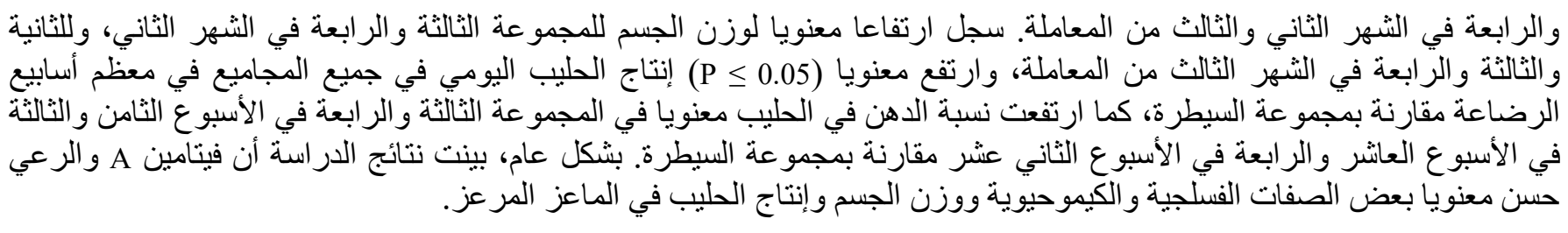

\section{Introduction}

Meriz goats are small and short-tailed goats, scattered in the northern region of Iraq (1). It is reared for the production of meat, hair and milk (2). These small ruminants are easy to handled and can withstand harsh conditions (3). Meriz goats color are white, red or brown and sometimes are a mixture of these colors. There is also an increase tendency to consume goat meat for many reasons including consumer desire for fat-free meat (4), also It is a good source of desirable fatty acids (5) which reduces the risk of heart diseases and atherosclerosis (6). Vitamin A is essential in feeding farm animals, and has vital functions in vision, bone growth, reproduction and maintenance of epithelial cells $(7,8)$. Green fodder is the main source of carotenoids which converted to vitamin A in the epithelial cells of intestinal mucosa and in the liver, it protects the body against diseases by enhancing the immune system (9). The use of grazing as a feed system in goat breeding is economic because of the ability of goats to utilize the poor pastures in harsh breeding conditions, producing high value nutritional products (10). The general state of the animal's body can be determined by the determination of its blood components in order to diagnose the disease condition accurately $(11,12)$ and the stress conditions (13). Due to the importance of Meriz goats in the field of productive performance, so that, the current study was carried to evaluate the effects of vitamin A injection and grazing in some physiological characteristics and production of milk and its components in meriz goats.

\section{Materials and methods}

\section{Study design}

The current study was conducted in the field of animal husbandry of the Livestock Department / College of Agriculture and Forestry / University of Mosul / Iraq. The study started at 15/2/2014 for 3 months. The study includes 28 does ( 2 years aged), after their birth, with average weight $22.57 \pm 0.47 \mathrm{~kg}$, the animals were housed in semiopen pens $\left(24 \mathrm{~m}^{2}\right.$ for each group), the animals were examined by the veterinarian and were healthy and diseasefree and were supervised by veterinarians throughout the study period with all the required vaccines. Table 1 represents the components of the ration that used in the study and table 2 represents the chemical analysis of the pasture plants that grazed by the animals. The concentrated ration was admitted to the animals at a rate of 750 $\mathrm{g} /$ animal/day, and the animals of each group were fed collectively, drinking water was freely available during the study period (Table 1). Chemical analysis was performed using the chemical analysis methods (14).

Table 1: Percentage of the components and chemical analysis of the rations used in in the study

\begin{tabular}{lc}
\hline Rations & Ingredients\% \\
\hline Barley & 50 \\
Wheat bran & 21 \\
Soybean meal $*$ & 8 \\
Yellow corn & 15 \\
Urea & 0.5 \\
Wheat straw & 4.5 \\
Food salt & 0.5 \\
CaCo3 & 0.5 \\
\hline Chemical analysis & \\
** Calculated chemical analysis\% & \\
\hline Dry matter & 90.22 \\
Organic matter & 92.33 \\
Raw Fiber & 4.95 \\
Ether extract & 2.60 \\
Protein & 14.13 \\
Dissolved carbohydrates & 70.10 \\
Ash & 5.40 \\
ME (Kcal/Kg/DM) & 2538.00 \\
\hline * Contains $44 \%$ crude protein
\end{tabular}

* Contains $44 \%$ crude protein.

** calculated as dry matter (15).

Table 2: Chemical analysis of pasture plants during the months of study / 2014

\begin{tabular}{ccccc}
\hline $\begin{array}{c}\text { Months } \\
\text { study }\end{array}$ & $\begin{array}{c}\text { Organic } \\
\text { matter } \%\end{array}$ & $\begin{array}{c}\text { Crude } \\
\text { protein } \%\end{array}$ & $\begin{array}{c}\text { Fat } \\
\%\end{array}$ & $\begin{array}{c}\text { Fiber } \\
\%\end{array}$ \\
\hline $1^{\text {st }}$ & 70.44 & 9.63 & 3.60 & 20.49 \\
$2^{\text {nd }}$ & 84.60 & 12.76 & 4.74 & 26.30 \\
$3^{\text {th }}$ & 92.10 & 9.45 & 5.02 & 28.30 \\
\hline
\end{tabular}

$1^{\text {st }}$ month: represent the period: 15 February - 15 March. $2^{\text {nd }}$ month: represent the period: 15 March - 15 April.

$3^{\text {rd }}$ month: represent the period: 15 April - 15 May.

Twenty-eight Meriz does were divided randomly into 4 groups ( 7 does / group), taking into account the absence of 
significant differences in the average weights between groups. The animals were weighed at the beginning of the study, then monthly using a sensitive disk balance, the treatment lasted for 3 months.

Group 1: 7 does with average weight $(22.57 \pm 0.47 \mathrm{~kg})$ reared on standard ration and injected with $0.05 \mathrm{ml}$ saline solution intramuscularly (control group). Group 2: 7 does with average weight $(22.52 \pm 0.63 \mathrm{~kg})$ reared on standard ration and injected with $0.05 \mathrm{ml}$ of Vitamin A - palmitate (50000 IU/ animal) intramuscularly once weekly. Group 3: 7 does with average weight $(22.42 \pm 0.53 \mathrm{~kg})$ reared on standard ration and allowed to graze for 6 hours daily, and injected with $0.05 \mathrm{ml}$ saline solution intramuscularly weekly. Group 4: 7 does with average weight $(22.48 \pm$ $22.64 \mathrm{~kg}$ ) reared on standard ration and injected intramuscularly with $0.05 \mathrm{ml}$ of Vitamin A - palmitate (50000 IU/ animal) once weekly and allowed to graze for 6 hours daily.

Blood samples were collected each month from the jugular vein, $10 \mathrm{ml}$ of blood was withdrawn and divided into two parts, the 1st part: $2 \mathrm{ml}$ was placed in plastic tubes containing Ethylene Diamin Tetra Acetic Acid (EDTA) and used for determination of hemoglobin $(\mathrm{Hb})$, Packed Cell Volume (PCV) and Erythrocytes Sedimentation Rate (ESR), the 2nd part of the blood samples $(8 \mathrm{ml})$ was placed in a plane glass tubes and the blood serum was separated by centrifugation (3000 cycles / $\mathrm{min}$ ) for 15 minutes, the serum were stored at $\left(-20^{\circ} \mathrm{C}\right)$ until used for biochemical tests.

$\mathrm{Hb}$ concentrations were determined by Cyanomethemoglobin method using Drabkin's reagent, PCV were determined by using capillary hematocrit tubes, ESR were determined by using the westergrean tubes (16).

The biochemical tests for blood glucose, cholesterol, triglycerides, total protein, albumin and globulin were estimated using the kits manufactured by Biolabo, Jordan, the samples values were measured by using a spectrophotometer.

The daily milk production was measured after 15 days of delivery by manual milking method. Births were isolated from their mothers at $8 \mathrm{pm}$, the udders were evacuated from milk completely, and at the next morning, milk production was measured after 12 hours of isolation using a sensitive balance, the results then multiplied by 2 to obtain the daily milk production (17). The milk was analyzed using an Ekomilk analyzer, the analysis includes fat, protein, lactose.

The statistical analysis was performed using one-way analysis of variance in the Statistical Analysis Statics Program (18), then Duncan's multiple range test (19) was used to test the differences between groups averages, according to the following mathematical model:

$\mathrm{Yij}=\mu+\mathrm{ti}+\mathrm{Eij}$

Yij $=$ the value of views, $\mathrm{M}=$ overall mean of observations, $\mathrm{Ti}=$ transaction effect, $\mathrm{Eij}=$ The experimental error effect.

\section{Results}

The results of the current study showed a significant increase $(\mathrm{P} \leq 0.05)$ in the $\mathrm{Hb}$ concentrations in the $4^{\text {th }}$ group (vitamin A and grazing) as compared with the other groups along the treatment period (Table 3), also the PCV of $4^{\text {th }}$ group does was significantly higher than the PCV values of the other groups does along the whole treatment periods except for the $2^{\text {nd }}$ (vitamin A) at the $3^{\text {rd }}$ month of treatment, on the other hand, the ESR values of the $3^{\text {rd }}$ group does (grazing) was significantly higher than values of the control group does.

Table (4) shows the effect of vitamin A and grazing on some biochemical parameters of the does, results revealed a significant increase in glucose values in $2^{\text {nd }}$ and $4^{\text {th }}$ groups $(62.21$ and $62.28 \mathrm{mg} / \mathrm{dl})$ respectively as compared with the control group $(60.96 \mathrm{mg} / \mathrm{dl})$ and the $3^{\text {rd }}$ group $(60.35 \mathrm{mg} / \mathrm{dl})$ at the $1^{\text {st }}$ month of treatment, in the $2^{\text {nd }}$ month of treatment there are a significant increase in the $2^{\text {nd }}, 3^{\text {rd }}$ and $4^{\text {th }}$ groups $(62.72,62.27$ and $62.45 \mathrm{mg} / \mathrm{dl})$ respectively as compared with control group $(60.21 \mathrm{gm} / \mathrm{dl})$, also the $2^{\text {nd }}$ and $4^{\text {th }}$ groups serum glucose values were significantly higher $(63.0$ and $63.31 \mathrm{mg} / \mathrm{dl})$ respectively than the values of $3^{\text {rd }}$ group does $(62.08 \mathrm{mg} / \mathrm{dl})$ and control group does $(61.0$ $\mathrm{mg} / \mathrm{dl}$ ). And in regard to the cholesterol values. Table 4 showed a significant decrease in the $4^{\text {th }}$ group (vitamin A and grazing) in the $2^{\text {nd }}$ and $3^{\text {rd }}$ months of treatment (57.82 and $57.57 \mathrm{mg} / \mathrm{dl}$ ) respectively as compared with cholesterol values of the other groups. On the other hand, the triglycerides values in does serum were significantly decreased in the control group at the $2^{\text {nd }}$ and $3^{\text {rd }}$ months of treatments $(104.51$ and $106.02 \mathrm{mg} / \mathrm{dl})$ respectively and in the $4^{\text {th }}$ group (vitamin A and grazing) at the $2^{\text {nd }}$ month of treatment $(104.75 \mathrm{mg} / \mathrm{dl})$ as compared with other groups values. And in regard to the effects of Vitamin A treatment and grazing on the serum proteins, table 5 revealed a significant increase $(\mathrm{P} \leq 0.05)$ in total protein and globulin at the $2^{\text {nd }}$ and $3^{\text {rd }}$ months in treatment groups as compared with control group.

On the other hand, there is a significant increase in does body weight in the $3^{\text {rd }}$ group (grazing only) and the $4^{\text {th }}$ group (vitamin A and grazing) at the $2^{\text {nd }}$ month of treatment (24.75 and $24.67 \mathrm{~kg}$ ) as compared with control $(23.32 \mathrm{~kg})$, and a significant increase in vitamin A group $(25.50 \mathrm{~kg})$, grazing group $(25.37 \mathrm{~kg}$ ) and vitamin A and grazing group $(25.91 \mathrm{~kg})$ as compared with control group $(23.97 \mathrm{~kg})$ at $3^{\text {rd }}$ month of treatment (Table 6). The effect of vitamin A and grazing on milk production and its components revealed a significant increase in daily milk production in the treatment's groups (vitamin A, grazing and vitamin A and grazing) at the $4^{\text {th }}, 6^{\text {th }}$ and $12^{\text {th }}$ weeks of treatment as compared with control group (Table 6). 
Table 3: Mean ( \pm SEM) Effect of vitamin A and grazing in some blood parameters of meriz goats

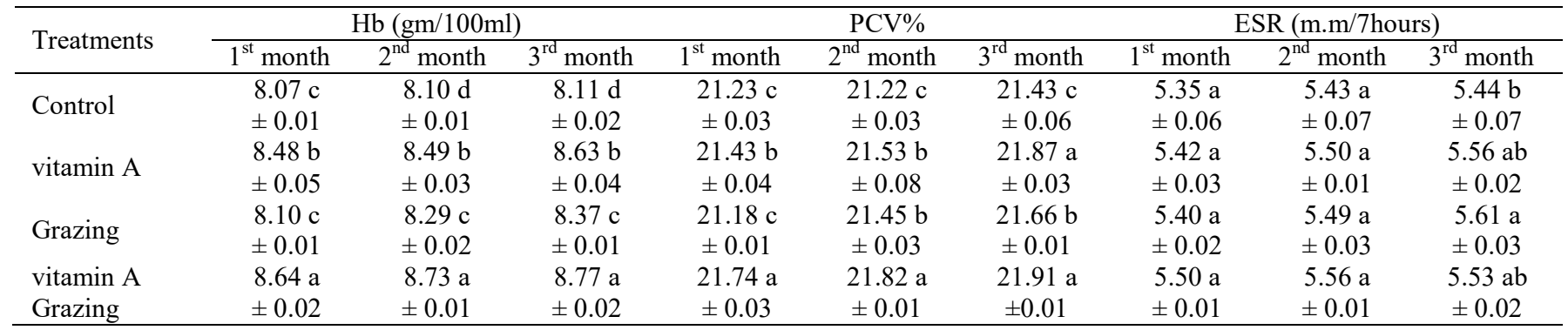

Values in the same column with different letters differ significantly $(\mathrm{P} \leq 0.05)$.

Table 4: Mean ( \pm SEM) Effect of vitamin A and grazing in some biochemical parameters of meriz goats

\begin{tabular}{|c|c|c|c|c|c|c|c|c|c|}
\hline \multirow{2}{*}{ Treatments } & \multicolumn{3}{|c|}{ Glucose $(\mathrm{mg} / 100 \mathrm{ml})$} & \multicolumn{3}{|c|}{ Cholesterol (mg/100ml) } & \multicolumn{3}{|c|}{ Triglycerides $(\mathrm{mg} / 100 \mathrm{ml})$} \\
\hline & $1^{\text {st }}$ month & $2^{\text {nd }}$ month & $3^{\text {rd }}$ month & $1^{\text {st }}$ month & $2^{\text {nd }}$ month & $3^{\text {rd }}$ month & $1^{\text {st }}$ month & $2^{\text {nd }}$ month & $3^{\text {rd }}$ month \\
\hline \multirow{2}{*}{ Control } & $60.96 \mathrm{~b}$ & $60.21 \mathrm{~b}$ & $61.00 \mathrm{c}$ & $70.51 \mathrm{a}$ & $59.61 \mathrm{a}$ & $58.48 \mathrm{a}$ & $90.66 \mathrm{a}$ & $104.51 b$ & $106.02 \mathrm{~b}$ \\
\hline & \pm 0.36 & \pm 0.05 & \pm 0.19 & \pm 0.22 & \pm 0.64 & \pm 0.14 & \pm 0.34 & \pm 0.30 & \pm 0.37 \\
\hline \multirow{2}{*}{ vitamin A } & $62.21 \mathrm{a}$ & $62.72 \mathrm{a}$ & $63.00 \mathrm{a}$ & $70.22 \mathrm{a}$ & $58.75 \mathrm{ab}$ & $58.08 \mathrm{a}$ & $91.12 \mathrm{a}$ & $106.73 \mathrm{a}$ & $110.63 a$ \\
\hline & \pm 0.16 & \pm 0.20 & \pm 0.21 & \pm 0.10 & \pm 0.21 & \pm 0.18 & \pm 0.25 & \pm 0.68 & \pm 0.50 \\
\hline \multirow{2}{*}{ Grazin } & $60.35 \mathrm{~b}$ & $62.27 \mathrm{a}$ & $62.08 \mathrm{~b}$ & $70.49 \mathrm{a}$ & $58.28 \mathrm{ab}$ & $58.16 \mathrm{a}$ & $90.73 \mathrm{a}$ & $106.89 \mathrm{a}$ & $111.62 \mathrm{a}$ \\
\hline & \pm 0.14 & \pm 0.18 & \pm 0.20 & \pm 0.13 & \pm 0.13 & \pm 0.14 & \pm 0.22 & \pm 0.36 & \pm 0.43 \\
\hline vitamin $\mathrm{A}$ & $62.28 \mathrm{a}$ & $62.54 \mathrm{a}$ & $63.31 \mathrm{a}$ & $70.33 \mathrm{a}$ & $57.82 \mathrm{~b}$ & $57.57 \mathrm{~b}$ & $90.45 \mathrm{a}$ & $104.75 b$ & $112.30 \mathrm{a}$ \\
\hline Grazing & \pm 0.26 & \pm 0.12 & \pm 0.12 & \pm 0.08 & \pm 0.63 & \pm 0.18 & \pm 0.10 & \pm 0.55 & \pm 1.67 \\
\hline
\end{tabular}

Values in the same column with different letters differ significantly $(\mathrm{P} \leq 0.05)$.

Table 5: Mean ( \pm SEM) Effect of vitamin A and grazing in some biochemical parameters of meriz goats

\begin{tabular}{|c|c|c|c|c|c|c|c|c|c|}
\hline \multirow{2}{*}{ Treatments } & \multicolumn{3}{|c|}{ Total Protein $(\mathrm{gm} / 100 \mathrm{ml})$} & \multicolumn{3}{|c|}{ Albumin $(\mathrm{gm} / 100 \mathrm{ml})$} & \multicolumn{3}{|c|}{ Globulin $(\mathrm{gm} / 100 \mathrm{ml})$} \\
\hline & $1^{\text {st }}$ month & $2^{\text {nd }}$ month & $3^{\text {rd }}$ month & $1^{\text {st }}$ month & $2^{\text {nd }}$ month & $3^{\text {rd }}$ month & $1^{\text {st }}$ month & $2^{\text {nd }}$ month & $3^{\text {rd }}$ month \\
\hline \multirow{2}{*}{ Control } & $6.94 \mathrm{a}$ & $6.75 \mathrm{~b}$ & $7.04 \mathrm{~b}$ & $4.20 \mathrm{a}$ & $4.83 \mathrm{a}$ & $4.88 \mathrm{a}$ & $2.73 \mathrm{a}$ & $1.90 \mathrm{~b}$ & $2.21 \mathrm{~b}$ \\
\hline & \pm 0.17 & \pm 0.21 & \pm 0.15 & \pm 0.04 & \pm 0.20 & \pm 0.16 & \pm 0.20 & \pm 0.15 & \pm 0.10 \\
\hline \multirow{2}{*}{ vitamin A } & $7.01 \mathrm{a}$ & $7.50 \mathrm{a}$ & $7.79 \mathrm{a}$ & $4.36 \mathrm{a}$ & $4.55 \mathrm{a}$ & $4.62 \mathrm{a}$ & $2.79 \mathrm{a}$ & $3.08 \mathrm{a}$ & $4.70 \mathrm{a}$ \\
\hline & \pm 0.22 & \pm 0.10 & \pm 0.05 & \pm 0.17 & \pm 0.14 & \pm 0.17 & \pm 0.12 & \pm 0.11 & \pm 0.15 \\
\hline \multirow{2}{*}{ Grazing } & $7.02 \mathrm{a}$ & $7.56 \mathrm{a}$ & $7.70 \mathrm{a}$ & $4.37 \mathrm{a}$ & $4.54 \mathrm{a}$ & $4.48 \mathrm{a}$ & $2.64 \mathrm{a}$ & $3.05 \mathrm{a}$ & $4.65 \mathrm{a}$ \\
\hline & \pm 0.22 & \pm 0.06 & \pm 0.07 & \pm 0.07 & \pm 0.10 & \pm 0.13 & \pm 0.19 & \pm 0.13 & \pm 0.13 \\
\hline vitamin $\mathrm{A}$ & $7.11 \mathrm{a}$ & $7.67 \mathrm{a}$ & $7.74 \mathrm{a}$ & $4.45 \mathrm{a}$ & $4.5 \mathrm{a}$ & $4.58 \mathrm{a}$ & $2.63 \mathrm{a}$ & $3.00 \mathrm{a}$ & $4.71 \mathrm{a}$ \\
\hline Grazing & \pm 0.20 & \pm 0.06 & \pm 0.06 & \pm 0.09 & \pm 0.11 & \pm 0.13 & \pm 0.17 & \pm 0.16 & \pm 0.20 \\
\hline
\end{tabular}

Values in the same column with different letters differ significantly $(\mathrm{P} \leq 0.05)$.

Table 6: Mean ( \pm SEM) Effect of vitamin A and grazing in body weight and daily milk gain $(\mathrm{gm})$ of meriz goats

\begin{tabular}{|c|c|c|c|c|c|c|c|c|c|c|}
\hline \multirow{2}{*}{ Treatment } & \multirow{2}{*}{$\begin{array}{c}\text { Initial } \\
\text { weight }\end{array}$} & \multicolumn{3}{|c|}{ Body weight (kg) } & \multicolumn{6}{|c|}{ Kidding weeks/ milk gain (gm) } \\
\hline & & $1^{\mathrm{st}}$ month & $2^{\text {nd }}$ month & $3^{\text {rd }}$ month & $2^{\text {nd }}$ week & $4^{\text {th }}$ week & $6^{\text {th }}$ week & $8^{\text {th }}$ week & $10^{\text {th }}$ week & $12^{\text {th }}$ week \\
\hline \multirow{2}{*}{ Control } & $22.57 \mathrm{a}$ & $23.35 \mathrm{a}$ & $23.32 \mathrm{~b}$ & $23.97 \mathrm{~b}$ & $625.00 \mathrm{a}$ & $661.42 \mathrm{~b}$ & $626.42 \mathrm{~b}$ & $562.14 \mathrm{~b}$ & $509.28 \mathrm{~b}$ & $521.42 \mathrm{~b}$ \\
\hline & \pm 0 & & & \pm & \pm & \pm & & \pm & & \\
\hline vitamin A & $\begin{array}{c}22.52 \mathrm{a} \\
\pm 0.63\end{array}$ & $\begin{array}{c}23.38 \mathrm{a} \\
\pm 0.42\end{array}$ & $\begin{array}{c}24.37 \mathrm{ab} \\
\pm 0.28\end{array}$ & $\begin{array}{c}25.50 \mathrm{a} \\
\pm 0.26\end{array}$ & $\begin{array}{c}628.57 \mathrm{a} \\
\pm 4.32\end{array}$ & $\begin{array}{c}757.85 \mathrm{a} \\
\pm 9.18\end{array}$ & $\begin{array}{c}699.28 \mathrm{a} \\
\pm 12.83\end{array}$ & $\begin{array}{c}623 \mathrm{a} \\
\pm 16.17\end{array}$ & $\begin{array}{c}587.14 \mathrm{a} \\
\pm 8.51\end{array}$ & $\begin{array}{c}549.28 \mathrm{a} \\
\pm 7.82\end{array}$ \\
\hline \multirow{2}{*}{ Grazing } & $22.42 \mathrm{a}$ & $23.60 \mathrm{a}$ & $24.75 \mathrm{a}$ & $25.37 \mathrm{a}$ & $624.28 \mathrm{a}$ & $731.42 \mathrm{a}$ & $670.14 \mathrm{a}$ & $607.14 \mathrm{~b}$ & $585.00 \mathrm{a}$ & $540.00 \mathrm{a}$ \\
\hline & \pm 0.53 & \pm 0.41 & \pm 0.35 & \pm 0.18 & \pm 1 & \pm 1 & \pm 17 & \pm 15.76 & \pm 16.32 & \pm 15.03 \\
\hline vitamin A & $22.48 \mathrm{a}$ & $23.74 \mathrm{a}$ & $24.67 \mathrm{a}$ & $25.91 \mathrm{a}$ & $630.71 \mathrm{a}$ & $741.42 \mathrm{a}$ & $705.41 \mathrm{a}$ & $625.00 \mathrm{a}$ & 605.71 a & $567.85 \mathrm{a}$ \\
\hline Grazing & \pm 0.64 & \pm 0.50 & \pm 0.36 & \pm 0.36 & \pm 14.03 & \pm 11.53 & \pm 6.70 & \pm 16.79 & \pm 14.45 & \pm 18.28 \\
\hline
\end{tabular}

Values in the same column with different letters differ significantly $(\mathrm{P} \leq 0.05)$. 
Milk fat \% (Table 7) increased significantly in grazing group and vitamin A with grazing at $8^{\text {th }}$ week of treatment $(3.87 \%$ and $3.74 \%)$ respectively as compared with control group $(3.49 \%)$ and vitamin A group $(3.50 \%)$, and in grazing group at $10^{\text {th }}$ week of treatment $(3.88 \%)$ as compared with control $(3.66 \%)$ and in vitamin A with grazing at $12^{\text {th }}$ week $(4.32 \%)$ as compared with control $(3.80 \%)$ at $(\mathrm{P} \leq 0.05)$ (Table 8$)$. On the other hand, there were no effects of the treatments on milk protein $\%$ and lactose $\%$ (Table 8 and 9).

Table 7: Mean ( \pm SEM) Effect of vitamin A and grazing in fat $\%$ of meriz goats milk

\begin{tabular}{lcccccc}
\hline \multirow{2}{*}{ Treatments } & \multicolumn{6}{c}{ Kidding weeks } \\
\cline { 2 - 7 } & $2^{\text {nd }}$ week & $4^{\text {th }}$ week & $6^{\text {th }}$ week & $8^{\text {th }}$ week & $10^{\text {th }}$ week & $12^{\text {th }}$ week \\
\hline \multirow{2}{*}{ Control } & $3.30 \pm 0.10$ & $3.02 \pm 0.08$ & $3.37 \pm 0.07$ & $3.49 \pm 0.05$ & $3.66 \pm 0.05$ & $3.80 \pm 0.04$ \\
& $\mathrm{a}$ & $\mathrm{a}$ & $\mathrm{a}$ & $\mathrm{b}$ & $\mathrm{b}$ & $\mathrm{b}$ \\
\multirow{2}{*}{ Vitamin A } & $3.33 \pm 0.10$ & $3.25 \pm 0.09$ & $3.37 \pm 0.10$ & $3.50 \pm 0.10$ & $3.71 \pm 0.09$ & $4.04 \pm 0.05$ \\
& $\mathrm{a}$ & $\mathrm{a}$ & $\mathrm{a}$ & $\mathrm{b}$ & $\mathrm{ab}$ & $\mathrm{ab}$ \\
\multirow{2}{*}{ Grazing } & $3.32 \pm 0.08$ & $3.26 \pm 0.08$ & $3.10 \pm 0.17$ & $3.87 \pm 0.02$ & $3.88 \pm 0.03$ & $4.05 \pm 0.12$ \\
\multirow{2}{*}{ vitamin A } & $\mathrm{a}$ & $\mathrm{a}$ & $\mathrm{a}$ & $\mathrm{a}$ & $\mathrm{a}$ & $\mathrm{ab}$ \\
& $3.25 \pm 0.06$ & $3.19 \pm 0.04$ & $3.29 \pm 0.04$ & $3.74 \pm 0.08$ & $3.38 \pm 0.04$ & $4.32 \pm 0.12$ \\
& $\mathrm{a}$ & $\mathrm{a}$ & $\mathrm{a}$ & $\mathrm{a}$ & $\mathrm{ab}$ & $\mathrm{a}$ \\
\hline
\end{tabular}

Values in the same column with different letters differ significantly $(\mathrm{P} \leq 0.05)$.

Table 8: Mean ( \pm SEM) Effect of vitamin A and grazing in protein $\%$ of meriz goats milk

\begin{tabular}{|c|c|c|c|c|c|c|}
\hline \multirow{2}{*}{ Treatments } & \multicolumn{6}{|c|}{ Kidding weeks } \\
\hline & $2^{\text {nd }}$ week & $4^{\text {th }}$ week & $6^{\text {th }}$ week & $8^{\text {th }}$ week & $10^{\text {th }}$ week & $12^{\text {th }}$ week \\
\hline Control & $3.30 \pm 0.10$ & $3.02 \pm 0.08$ & $3.37 \pm 0.07$ & $3.49 \pm 0.05$ & $3.66 \pm 0.05$ & $3.80 \pm 0.04$ \\
\hline Control & $\mathrm{a}$ & $\mathrm{a}$ & $\mathrm{a}$ & $\mathrm{b}$ & b & b \\
\hline Vitamin A & $\begin{array}{c}3.33 \pm 0.10 \\
\mathrm{a}\end{array}$ & $\begin{array}{c}3.25 \pm 0.09 \\
\mathrm{a}\end{array}$ & $\begin{array}{c}3.37 \pm 0.10 \\
\mathrm{a}\end{array}$ & $\begin{array}{c}3.50 \pm 0.10 \\
\mathrm{~b}\end{array}$ & $\begin{array}{c}3.71 \pm 0.09 \\
\mathrm{ab}\end{array}$ & $\begin{array}{c}4.04 \pm 0.05 \\
\mathrm{ab}\end{array}$ \\
\hline Grazing & $\begin{array}{c}3.32 \pm 0.08 \\
\mathrm{a}\end{array}$ & $\begin{array}{c}3.26 \pm 0.08 \\
\mathrm{a}\end{array}$ & $\begin{array}{c}3.10 \pm 0.17 \\
\mathrm{a}\end{array}$ & $\begin{array}{c}3.87 \pm 0.02 \\
\mathrm{a}\end{array}$ & $\begin{array}{c}3.88 \pm 0.03 \\
\mathrm{a}\end{array}$ & $\begin{array}{c}4.05 \pm 0.12 \\
\mathrm{ab}\end{array}$ \\
\hline vitamin $\mathrm{A}+$ Grazing & $\begin{array}{c}3.25 \pm 0.06 \\
\mathrm{a}\end{array}$ & $\begin{array}{c}3.19 \pm 0.04 \\
\mathrm{a}\end{array}$ & $\begin{array}{c}3.29 \pm 0.04 \\
\mathrm{a}\end{array}$ & $\begin{array}{c}3.74 \pm 0.08 \\
\mathrm{a}\end{array}$ & $\begin{array}{c}3.38 \pm 0.04 \\
\mathrm{ab}\end{array}$ & $\begin{array}{c}4.32 \pm 0.12 \\
\mathrm{a}\end{array}$ \\
\hline
\end{tabular}

Values in the same column with different letters differ significantly $(\mathrm{P} \leq 0.05)$.

Table 9: Mean ( \pm SEM) Effect of vitamin A and grazing in lactose $\%$ of meriz goats milk

\begin{tabular}{|c|c|c|c|c|c|c|}
\hline \multirow{2}{*}{ Treatments } & \multicolumn{6}{|c|}{ Lactating weeks } \\
\hline & $2^{\text {nd }}$ week & $4^{\text {th }}$ week & $6^{\text {th }}$ week & $8^{\text {th }}$ week & $10^{\text {th }}$ week & $12^{\text {th }}$ week \\
\hline Control & $3.30 \pm 0.10$ & $3.02 \pm 0.08$ & $3.37 \pm 0.07$ & $3.49 \pm 0.05$ & $3.66 \pm 0.05$ & $3.80 \pm 0.04$ \\
\hline & $\mathrm{a}$ & $\mathrm{a}$ & $\mathrm{a}$ & B & $\mathrm{b}$ & b \\
\hline Vitamin A & $\begin{array}{c}3.33 \pm 0.10 \\
\mathrm{a}\end{array}$ & $\begin{array}{c}3.25 \pm 0.09 \\
\mathrm{a}\end{array}$ & $\begin{array}{c}3.37 \pm 0.10 \\
\mathrm{a}\end{array}$ & $\begin{array}{c}3.50 \pm 0.10 \\
B\end{array}$ & $\begin{array}{c}3.71 \pm 0.09 \\
\end{array}$ & $\begin{array}{c}4.04 \pm 0.05 \\
\mathrm{ab}\end{array}$ \\
\hline Grazing & $\begin{array}{c}3.32 \pm 0.08 \\
\mathrm{a}\end{array}$ & $\begin{array}{c}3.26 \pm 0.08 \\
\mathrm{a}\end{array}$ & $\begin{array}{c}3.10 \pm 0.17 \\
\mathrm{a}\end{array}$ & $\begin{array}{c}3.87 \pm 0.02 \\
\text { A }\end{array}$ & $\begin{array}{c}3.88 \pm 0.03 \\
\mathrm{a}\end{array}$ & $\begin{array}{c}4.05 \pm 0.12 \\
\mathrm{ab}\end{array}$ \\
\hline vitamin $\mathrm{A}+$ Grazing & $\begin{array}{c}3.25 \pm 0.06 \\
\mathrm{a}\end{array}$ & $\begin{array}{c}3.19 \pm 0.04 \\
\mathrm{a}\end{array}$ & $\begin{array}{c}3.29 \pm 0.04 \\
\mathrm{a}\end{array}$ & $\begin{array}{c}3.74 \pm 0.08 \\
\mathrm{~A}\end{array}$ & $\begin{array}{c}3.38 \pm 0.04 \\
\mathrm{ab}\end{array}$ & $\begin{array}{c}4.32 \pm 0.12 \\
\mathrm{a}\end{array}$ \\
\hline
\end{tabular}

Values in the same column with different superscripts differ significantly $(\mathrm{P} \leq 0.05)$.

\section{Discussion}

The results of the study were in consistent with the results of Araz and Bamerny (20) in their study about the effects of vitamin $A$ on the performance of the phytoplankton sheep, vitamin A increased the concentration of hemoglobin and PCV. The results in agreement with results of Adejumo (21), who study the blood parameters does after birth. The improvement of these blood qualities in the fourth treatment (vitamin A and grazing) may be due 
to the improvement of nutritional status, which is an evidence of good health of animals (22). Vitamin A also plays an important role in supporting growth, health and reproduction as well as cell maturation (23), and the moral rise of ESR values in 3rd group (grazing only) at the third month of treatment may due to the loss of red blood cells during the last parturition, or because of the dilution due to increased plasma blood volume during the period of milking due to increased water drinking by animals (24). The concentration of total protein in the blood reflects the health and metabolic status of the animal as well as the level of nutrition and environmental conditions surrounding the animal (25), since vitamin A has a role in supporting growth and health as well as the maturation of cells (23) and enhancing nutrition $(26,27)$. this fact was supported by the high level of protein in pasture plants (Table of total protein concentration in the increase of total protein concentration in the does serum and the increase in globulin concentration may be due to Vitamin A role in sustaining the immune system (9). The result of current study were in consistent with the results of Abdul-Rahman et al. (28) who recorded that rearing lambs on concentrated ration and grazing causes a significant increase in body weight as compared with lambs reared on concentrated ration only, also it agreed with the results of Taylor et al. (29) which revealed that rearing lambs on concentrated ration and grazing showed a significant increase in body weight as compared with lambs reared on concentrated ration only. The improvement of body weight in group of vitamin A and the group of grazing may be due to vitamin A ability in sustaining growth as well as cell maturation and protection against diseases (23). Grazing also provide essential proteins and nutrients for animal vital functions (30). The significant increase in daily milk production due to vitamin A treatment may be due to the important role of vitamin A as antioxidant as it enhances protein and body growth (31), also it activates the epithelial cells including the milk secreting cells of mammary alveoli (7 and 8 ). The increase in milk production due to grazing was inconsistent with the results of Al-Dabbagh (32) who recorded that Merino ewes which reared on concentrated ration with grazing. The reason for the increase in milk production may be due to the high body weight of ewes (33) recorded high significant effect of mother's body weight on daily milk production. The significant increase in fat $\%$ in dose's milk at 8th and 10th week of treatment, was consistent with the results obtained by Al-Dabbagh (32), who recorded a significant increase in fat $\%$ in grazing group of Merino ewes as compared with the ewes reared on concentrated ration only.

The increase of fat $\%$ in grazing group of current study was due to consuming coarse grazing plants, which leads to increased milk content of fat (33), also the nutritional value of pasture plants was better in March and April. In conclusion, vitamin A and vitamin A with grazing improve some physiological parameters as $\mathrm{Hb}$ and $\mathrm{PCV}$ as well as total protein and globulin which was reflected on the sustaining milk production and improving its components.

\section{References}

1. Alkass E, Kawa Y. Meriz goat in Kurdistan region/Iraq: A Review. Advan J Agri Res. 2013;1(7):105-111.Available at https://www.researchgate.net/publication/272497251.

2. Alkass JE, Merkhan KY. Milk production traits of indigenous Black and Meriz goats raised under farm production system. Res Opin Anim Vet Sci. 2011;1(11):708-713. https://www.researchgate.net /publication/272421657t

3. Kawa YM, Jalal EA. A study on milk composion of black and Meriz goats raised under farm condition. J Uni Duhok. 2012;15(1):1-12. Available at https://www.researchgate.net/profile/Kawa_Merkhan

4. Potchoiba MJ, Lu CD, Pinkerton F, Sahlu T. Effects of all-milk diet on weigt gain, organ development, carcass characteristics and tissue composition, including fatty acid and cholesterol contents of growing male goats. Small Rumin Res. 1990;3:583-592. Available at https://www.sciencedirect.com/science/article/abs/pii/0921448890900 539.

5. Banskalieva V, Sahlu T, Goetsch AL. Fatty acid composition of goat muscles and fat depots: a review. Small Rumin Res. 2000;37:255-268. Available at https://www.ncbi.nlm.nih.gov/pubmed/10867324

6. Stankov IK, Todorov NA, Mitev JE, Miteva TM. Study on some qualitative features of meat from young goat of Bulgarian breeds and crossbreds of goats slaughtered at various ages. Asian-Australian J Anim Sci. 2002;15,283-289. Available at https://scialert.net/abstract/ ?doi=ajas.2016.262.267

7. Zervos IA, Tsantarliotou MP, Vatzias G, Goulas P, Kokolis NA, Taitzoglou IA. Effect of dietary Vitamin A intake on acrosin and plasminogen- activator activity of ram spermatozoa. Repro. 2005;129:707-715. Available at https://www.academia.edu/21718550

8. Giadinis ND, Papaioannou N, Tsaousi P, Koutsoumpas A, Fytianou A, Karatzias H. Vertebral absence in a lamb with Vitamin A deficiency. Pak Vet J. 2012;32:295-297. https://www.researchgate.net /publication/279906695

9. Underwood BA. Vitamin A in animal and human nutrition. $1^{\text {st }}$ ed. New York: Academic Press; 1984. 282-392 p. Available at https://onlinelibrary.wiley.com/doi/book/10.1002/9780470376911

10. Decandia M, Molle G, Pinna G, Cabiddu A, Yiakoulaki M. Comportamento alimentare ed ingestion di capre al pascolo su macchia mediterranea. Bologna; Avenue Media; 2005. 173-207 p.

11. Tambuwal FM, Agale BM, Bangana A. Hematological and Biochemical Values of Apparently Healthy Red Sokoto Goats. Proceedings of 27th Annual conference Nigerian society of Animal production (NSAP) March 17-21, FOTA, Akure; 2002.

12. Alade AA, Bambose AM, Ogutona EB, Fanimo AO. Hematological Parameters, serum metabolites carcass Characteristic of Weaner Rabbits Fed Yam Feel Meal Diets. Proceedings of 10th annual conference of Animal science Association of Nigeria Dairo, F.A.S. So. K Fajemilehin and G.E Onobi (Eds) held on 12-15 September at university of Ado-Ekiti, Nigeria. 2005; 280-282 p.

13. Aderemi FA. Effects of replacement of wheat bran with cassava root seriate supplemented of with enzyme on the Hematology and serum biochemistry of pullet chicks. Trop J Animal Sci. 2004;7:147-153. Available at http://www.lrrd.org/lrrd25/10/kana25177.htm .

14. Al-Khawaja AK, Al-Bayati EA, Mati SA. Chemical Composition and Nutritional Value of Iraqi Feedstuffs (Bulletin issued by the Ministry of Agriculture and Agrarian Reform, Republic of Iraq). 1978.

15. Jain NC. Haemotological Techniques in: Schalmis veterinary Haematology. Lea and Febiger Philadelphia. 1986:20-86. Available at https://www.worldcat.org/title/schalms-veterinaryhematology/oclc/11517684at 
16. Arab Organization for Agricultural Development. Annual Bulletin of Arab Agricultural Statistics. 1995;15: 1-23. Available at http://www.aoad.org/priod_en.htm

17. Arab Organization for Agricultural Development (1995). Annual Bulletin of Arab Agricultural Statistics. Volume 15, Khartoum.

18. SAS. Statistical Analysis Systems. New York: SAS Institute, 9.1 User's Guide. Cary; 2004.

19. Steel, R.G.D. and Torrie, J.H. (1984) Principles and Procedures of Statistics: A Biometrical Approach. 2nd McGraw Hill Book Co., Singapore.

20. Abdelhamid AM, El-Ayouty SA, Arief HS. Effect of feed intake and dietary vitamin A levels on sheep performance. Arch Tierernahr. 1992;42(3-4):325-350.

21. Araz O, Bamerny A. Changes in some haemato-biochemical and electrolytes parameters in female meriz goats during pregnancy and after parturition. J Anim Sci. 2013;2(1):11-14.

22. Adejumo DO. Performance, organ development and hematological of rats ted sole diets of graded levels of cassava flour and soybean flour (soy gari) as substitutes for energy and protein concentrates. Trop J Animal Sci. 2004;7:57-63.

23. McLaren DS, Frigg M. Sight and Life manual on vitamin A deficiency disorders (VADD) (2nd ed.). Task Force Sight and Life, Basel, Switzerland. 2001. http://www.who.int/ncd/vision 2020_actionplan/ documents/00allman.pdf.

24. El-Sherif MMA, Assad A. Change in some blood constituents of Barki ewes during pregnancy and lactation under semi arid conditions. Small Rumi Res. 2001:40:269-277.

25. Coles EA. Veterinary Clinical Pathology. $4^{\text {th }}$ ed. London: Sannders WB Co; 1986. 124-127 p.
26. Al- Hamdani KH, S. Effect of feeding systems and hormonal treatment on some productive and reproductive performance aspects in awassi sheep [PhD dissertation]. Mosul: College of Agriculture and Forestry, University of Mosul; 2012. 126 p.

27. Sultan KH. Effect of grazing and injections of vitamin A in semen characteristics and concentration of sexual hormones of awassi rams. Tikrit Uni J Agri Sci. 2013;13(4):73-80.

28. Sultan KH, Saeb YA, Radi KA. Effect of some feeding systems and hormonal treatments on reproductive performance and growth of lambs in Awassi ewes. J Mesopotamia. 2012;40(2):33-43.

29. Abdul-Rahman SY, Rathi KA, Khalid HS. Effect of grazing and feeding frequency on some productive characteristics and semen quality of Awassi lambs. Res Opin Anim Vet Sci. 2011;1(10):644649.

30. Taylor N, Hatfield PG, Sowell BF, Lewis GS. Research Note Influence of supplement form on ewe performance and reproduction. Sheep Goat Res J. 2002;17(2):52-54.

31. Zubay G. Lipid soluble vitamin. $3^{\text {rd }}$ Edition. Oxford: WMC Brown Publishers; 2001.301 p.

32. Braghieri AC, Pacelli M, Verdone A, Girolami F, Napolitano F. Effect of grazing and homeopathy on milk production and immunity of Merino derived ewes. Small Rum Res. 2007;69:95-102.

33. Al-Dabbagh SFMS. Comparing the productive and physiological performance of milk and wool in Awassi and Hamdani ewes [PhD dissertation]. Mosul: College of Agriculture and Forestry, University of Mosul; 2009. $193 \mathrm{p}$.

34. Yves M, Berger B, Pierrc B, Francoisand C, Gerardo A. Principles of sheep dairying in north America. Board of regents of the University of Wisconsin. USA; 2004 